\title{
Conversion Coefficients for Distilling Wood in Running Standards and Everyday
}

\section{Practice}

Srđan Ljubojević

University of Banja Luka

Stepe Stepanovića 75a

78000 Banja Luka

Bosnia and Herzegovina

ljuboje@yahoo.com
Dane Marčeta

University of Banja Luka

Stepe Stepanovića 75a

78000 Banja Luka

Bosnia and Herzegovina

danemarceta@gmail.com
Slobodan Kremenović

University of Banja Luka

Stepe Stepanovića 75a

78000 Banja Luka

Bosnia and Herzegovina

kremenovic11@yahoo.com

\section{Abstract}

Background and purpose: Need for distilling wood is rather significant on the wood market in Republic of Srpska. Delivering of distilling wood is done according JUS standard. Purpose of this research was to explore how much this standard is appropriate for present assortment of wood which deliver and use as distilling wood, and what are main problems.

Material and methods: Research was conducted at the premises of the company "Destilacija" a.d. Teslic. It was selected samples of distillation wood in a random manner, so as to check accuracy of conversion factors stated in the delivery note. Subject of interest were loads with one-meter log wood for distillation. Conversion coefficients are determined by using xylometry method and dendrometric method.

Results and conclusions: Conversion factor based on xylometry varies considerably between $0.45-58$. Results lead to the conclusion that appliance of officially prescribed conversion factor leads to over estimation of delivered distillation wood. Also results of dendrometric measurements and calculating of volume show that conversions factors are significantly lower than those one obtain with the xylometry 0.36-0.52. Main reason for that may laying in the fact that measurements was done according to JUS which prescribes measurement with rounding down for diameter (round centimeters) and length (round decimeters). Dendrometric measurement according JUS is not appropriate for assortments from the category of staked wood. Conversion coefficients must be determined for different moisture content. One solution for described gap may be shift to weight scaling. In that case mistakes caused by measurement could be avoided but it must be considered moisture of wood also. Wood for distilling should be as dry as much as possible before use, around $20 \%$ moisture content.

Key words: distilling wood, conversion coefficients, $x y$ lometry method.

\section{INTRODUCTION}

Distillation of wood in industrial scale had begun in Bosnia and Herzegovina in 1896. That year had been established Bosnian joint stock company for wood processing (Bosnische Holzvewertungs - Aktiengesellshaft) situated in the town Teslic [1]. Main task of this company was to process 120000 stacked cubic meters per year of beech distillation wood in charcoal crucible, and to deliver all of produced quantities (around 130000 metric tons) to the Steel industry in the town of Vares. At that time, industrial plant in Teslic had been among the biggest of it's kind in Europe, with daily capacity of 400 stacked cubic meters. Apart of charcoal crucible, factory had produced coarse wood vinegar, methyl alcohol and acetone, as well as number of other derivates with provided placement on the world market.

Industrial plant in Teslic sustain to this days, under the name Chemical Industry "Destilacija" a.d. Teslic [2]. Annual quantity of processed wood amounted 80000 solid cubic meters. From this raw material the following items are produced: charcoal crucible, shell (nut) charcoal, acetic acid, powder for hardening steel, acetates, antifreeze, diluents, solvents and other products.

Greater part of raw material comes as round wood between $2 \mathrm{~m}$ and $6 \mathrm{~m}$ in length. Smaller part comes as one-meter firewood (log wood, billets) in round and split pieces. Round wood is calculated in a solid cubic meter. Single pieces volume under bark is determined according to Huber's Cubic Volume formula. Log wood processed in stump area or by the roadside, is being ordered in stacks of prismatic shape. Log wood is calculated in a stacked cubic meter or stere (stére) which describes a cube with an edge length of $1 \mathrm{~m} \times 1 \mathrm{~m} \times 1 \mathrm{~m}$, including air gaps between 


\section{TABLE 1}

Review of volume conversion factors for various typed of stocked round wood, used in former Yugoslavia (source $[9,10]$ )

\begin{tabular}{|c|c|c|c|c|}
\hline & Types of stacked round wood & $\begin{array}{c}\text { JUS D.B0.022 } \\
(1984)\end{array}$ & $\begin{array}{c}\text { Horvat \& Krpan } \\
(1967)\end{array}$ & $\begin{array}{c}\text { Gornik-Bučar \& Merzelj } \\
(1988)\end{array}$ \\
\hline 1 & Billets (split logs) over bark & 0.80 & $0.70-0.75$ & 0.80 \\
\hline 2 & Billets (split logs) under bark & & & 0.75 \\
\hline 3 & Logs (rounds) over bark & 0.75 & $0.65-0.70$ & 0.80 \\
\hline 4 & Logs (rounds) under bark & & & 0.70 \\
\hline 5 & Pulpwood debarked & & & 0.69 \\
\hline 6 & Rough puplpwood (with bark) & 0.70 & & 0.30 \\
\hline 7 & Fire wood & 0.69 & & \\
\hline 8 & Small round billets & 0.55 & $0.40-0.50$ & \\
\hline 9 & Stump wood & 0.45 & $0.45-0.50$ & \\
\hline 10 & Forest residues & 0.40 & & 0.30 \\
\hline 11 & Chips & 0.37 & & $0.50-0.65$ \\
\hline 12 & Bur (burr) & & & \\
\hline 13 & Bark & & & \\
\hline
\end{tabular}

the woodblocks. Conversion of volume of stacked cubic meters into appromaximate volume of solid cubic meters is conducted by using appropriate conversion factors. According to existing national standard (JUS D.B5.023) [3] distillation wood is equalized with firewood of hardwoods including small round billets (with mid. diameter under bark 3-7 cm), but the share of the later assortment is not prescribed. For these assortments, national standard (JUS D.B0.022) [4] requires conversion factor equal to 0.69 for firewood and 0.55 for small round billets. According to the principle „take it or live it", public forest company calculated common (average) conversion factor equal to 0.65 on delivery.

Considering that Chemical industry "Destilacija" a.d. Teslic consumes rather big amount of raw material, there is necessity for an accurate estimation of wood consumption in industrial processes, particularly when it comes to one-meter firewood.

Conversion factors that exists in literature or are in the practical use in other countries differs from conversion factors prescribed by national standard, and as such are not applicable to the local conditions [5, $6,7,8]$. With that regard, this paper deals with detail analyze of the real volume of distilled wood (i.e. firewood) at unloading ramp, applying dendrometric and xylometric methods. On the basis of such research, authors have come to the novel conversion factors which are more accurate with the real situation. Therefore, the aim of this research was to revise

\section{TABLE 2}

Review of volume conversion factors for various shapes of stocked round wood, used in foreign countries (source $[11,12,13]$ )

\begin{tabular}{|c|c|c|c|c|}
\hline & Shapes of stacked round wood & $\begin{array}{c}\text { Pirinen } \\
(1996)\end{array}$ & $\begin{array}{c}\text { Kofman } \\
(2006)\end{array}$ & $\begin{array}{c}\text { Jennings } \\
(1965)\end{array}$ \\
\hline 1 & Round wood measuring 2 m in length & & 0.65 & \\
\hline 2 & Round wood measuring 3 m in length & & 0.55 & \\
\hline 3 & One-meter firewood, neatly stacked & 0.62 & & \\
\hline 4 & One-meter firewood, loosely packed & 0.40 & & \\
\hline 5 & $\begin{array}{c}\text { Firewood in ready-to-burn logs, in round and split } \\
\text { pieces, 33 cm long, neatly stacked }\end{array}$ & 0.67 & $0.75-0.80$ & \\
\hline 6 & $\begin{array}{c}\text { Firewood in ready-to-burn logs, in round and split } \\
\text { pieces, 33 cm long, loosely packed }\end{array}$ & 0.40 & $0.45-0.50$ & \\
\hline 7 & Pulpwood debarked & & & 0.75 \\
\hline 8 & Rough pulpwood (with bark) & & & 0.65 \\
\hline
\end{tabular}


accuracy of conversion factors in use, and to recommend ones that are more appropriate to the field conditions.

\section{MATERIALS AND METHODS}

Research was conducted at the premises of the company "Destilacija" a.d. Teslic. There we selected 16 samples of distillation wood in a random manner, so as to check accuracy of conversion factors stated in the delivery note. Subject of our interest were only loads with one-meter log wood for distillation.

Survey of standards relevant to distillation wood

There are two national standards dealing with distillation wood: Classification and measuring of unworked and worked timber (JUS D.B0.022) and Heatwood and distillation (JUS D.B5.023); (JUS was an acronym for Jugoslav standards, later renamed with an acronym SRPS for Serbian standards).

According to JUS D.B5.023 (i.e. SRPS D.B5.023) distillation wood is equalized with firewood of hardwoods including small round billets with mid. diameter under bark 3-7 cm, where under hardwoods are considered: beech, hornbeam, oak, locust, maple, ash, elm, field maple wood and fruit trees.

According to the moisture or time after cutting, this wood is classified as a dry (seasoned) if cut at least 6 months before delivery, in winter or in summer, or as a raw (green) if cut less than 4 month before delivery.

According to the shape of pieces, standard differs:

a. Billets: pieces of wood $1 \mathrm{~m}$ in length, obtained by splitting of round wood at least $15 \mathrm{~cm}$ in diameter, with both ends cut by saw. Chord of arc or flat side of billet ought to be $10-25 \mathrm{~cm}$ wide. Tolerances of length are $+/-5 \mathrm{~cm}$. b. Logs: pieces of wood obtained by sawing of round wood, one meter long, with diameter $7-25 \mathrm{~cm}$. Tolerances of length are $+/-5 \mathrm{~cm}$.

c. Small round billets, obtained by cutting with axe or saw, $90-120 \mathrm{~cm}$ in length, with diameter 3-7 $\mathrm{cm}$.

d. Bur: gnarled, easy or hard to split pieces of wood, length 0.5-1.2 m, with diameter $25-40 \mathrm{~cm}$.

e. Stump wood: pieces of wood obtained by breaking or splitting stumps, $15-40 \mathrm{~cm}$ thick.

$f$. Wood remains: pieces of wood remain after cutting, sawing, splitting and debarking of wood in forest or at sawmills. Dimensions of pieces vary between $0.5-25 \mathrm{~cm}$ in thickness, $2-25 \mathrm{~cm}$ in wideness and $15-120 \mathrm{~cm}$ in length.

According to the quality, wood is assorted in two classes, the first and the second. In the 1 st class the following defects of wood are acceptable: knots of all sizes and types; partially decayed pieces, up to 10 $\%$ of shipment; incipient rottenness of wood, up to $30 \%$ of shipment; up to $15 \mathrm{~cm}$ distance between the rounded concave longitudinal surface and a straight line joining the innermost points of the surface, spiral grain with no limit.

Acceptable defects for the $2^{\text {nd }}$ class are slightly higher than for the $1^{\text {st }}$ class, as follows: knots, of all sizes and types; sweep and spiral grain with no limits; partially decayed pieces, up to $20 \%$ of shipment; incipient rottenness of wood, up to $50 \%$ of shipment; short pieces, up to $10 \%$ of shipment.

Distillation wood comes in prismatic piles, which volume is expressed in a stacked cubic meter. Conversion of this volume into approximate volume of solid cubic meter is conducted by using appropriate conversion factor (JUS D.B5.023), given in Table 1. For the sake of comparison, in Tables 2 and 3 are given

\section{TABLE 3}

Volume conversion factors in dependence of diameter, length and shape of stocked round wood pieces according to Flann (source [14])

\begin{tabular}{|c|c|c|c|c|c|c|}
\hline Mid. diameter (cm) & \multicolumn{2}{|c|}{15} & \multicolumn{2}{c|}{20} & \multicolumn{2}{c|}{30} \\
\hline Length (m) & 1.2 & 2.4 & 1.2 & 2.4 & 1.2 & 2.4 \\
\hline Shape of pieces & V O L U M E C O N V E R S I O N F A C T O R S (m $3 /$ stere) \\
\hline S O F T W O O D S & 0.70 & 0.69 & 0.74 & 0.73 & 0.78 & 0.77 \\
\hline Straight and smooth & 0.66 & 0.63 & 0.71 & 0.69 & 0.75 & 0.73 \\
\hline Straight, slightly rough and knotty & 0.63 & 0.59 & 0.69 & 0.66 & 0.73 & 0.71 \\
\hline Slightly crooked and rough & 0.55 & 0.51 & 0.62 & 0.59 & 0.65 & 0.63 \\
\hline Crooked, rough and knotty & \multicolumn{7}{|c|}{} \\
\hline H A R D W O O D S & 0.66 & 0.64 & 0.71 & 0.69 & 0.77 & 0.74 \\
\hline Straight and smooth & 0.61 & 0.57 & 0.66 & 0.64 & 0.72 & 0.70 \\
\hline Straight, slightly rough and knotty & 0.59 & 0.55 & 0.64 & 0.62 & 0.70 & 0.67 \\
\hline Slightly crooked and rough & 0.52 & 0.47 & 0.59 & 0.55 & 0.61 & 0.59 \\
\hline
\end{tabular}




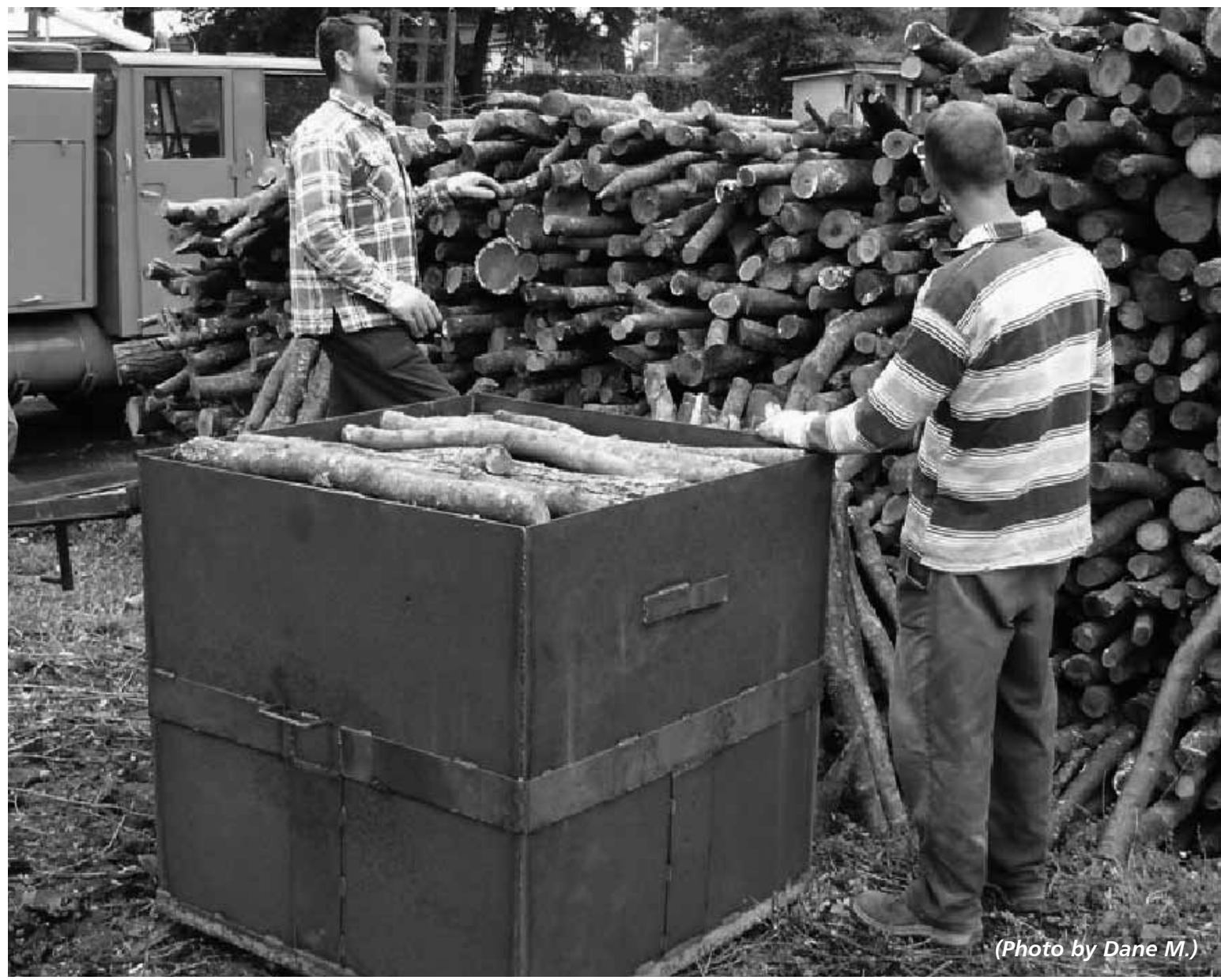

FIGURE 1

Wood stacked and prepared for sinking

conversion factors that exist in literature or are in the practical use in other countries.

Upon unloading at the receiving site, each shipment was stacked into prismatic pile. From each load we took three stacked cubic meters of wood as a sample, positioned at the beginning, in the middle and at the end of the pile. Each and every piece of wood was measured in dendrometric sense using traditional formulas of Huber, Smalian and Riecke in order to estimate it's volume and the volume of one stacked cubic meter of wood. Diameter was measured over bark with manual calliper. One measurement was made for pieces thinner than $20 \mathrm{~cm}$, and two for the others. Diameter was expressed in centimeters, rounded down. Length was measured as the shortest distance between two parallel sides, using meter tape. Length was expressed in meters to one decimal place rounded down (JUS D.B0.022, EN 1309-2) [15]. At the same time, water displacement (xylometry) was used to determine true volumes of observed pieces of wood.

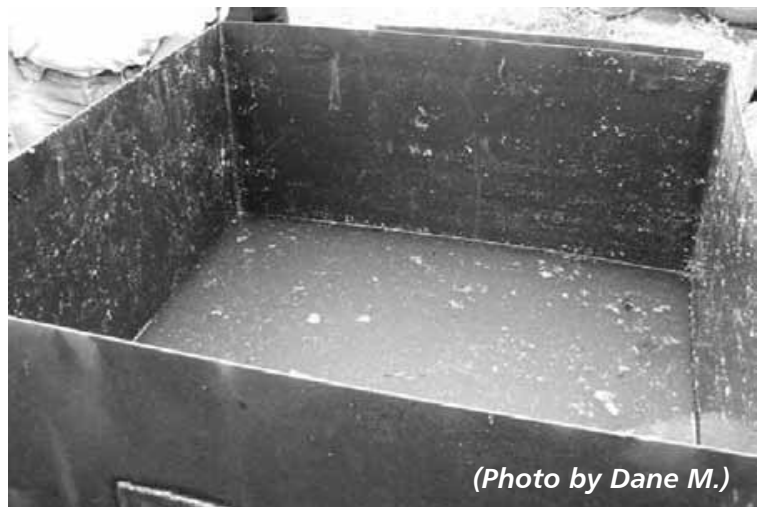

FIGURE 2

Vessel with remaining water

Xylometry is well known in science and in practice. It is based on the simple principle that volume of a body is equal to water mass displaced by it body. There are various methods used with xylometry, measuring the increase in water level, the increase in weight of the xylometer or the decrease in weight of the object, and converting weight change to change 
TABLE 4

General review of collected data

\begin{tabular}{|c|c|c|c|c|c|c|c|c|c|c|c|c|c|c|c|c|}
\hline Sample No. & 1 & 2 & 3 & 4 & 5 & 6 & 7 & 8 & 9 & 10 & 11 & 12 & 13 & 14 & 15 & 16 \\
\hline $\begin{array}{c}\text { Number of pieces } \\
\text { in one stacked } \\
\left(\mathrm{m}^{3}\right)\end{array}$ & 130 & 124 & 114 & 112 & 132 & 127 & 124 & 148 & 80 & 82 & 67 & 63 & 84 & 68 & 54 & 79 \\
\hline $\begin{array}{c}\text { Aver. diameter } \\
\text { (cm) }\end{array}$ & 5.7 & 6.1 & 6.2 & 6.5 & 5.4 & 5.7 & 5.8 & 5.1 & 8.1 & 8.0 & 8.8 & 9.4 & 8.0 & 9.0 & 9.5 & 7.9 \\
\hline $\begin{array}{c}\text { Percentage of } \\
\text { pieces with mid. } \\
\text { diameter } \\
<7 \mathrm{~cm}(\%)\end{array}$ & 76 & 71 & 72 & 62 & 77 & 68 & 71 & 84 & 37 & 35 & 26 & 29 & 35 & 16 & 13 & 24 \\
\hline $\begin{array}{c}\text { Perc. of pieces } \\
\text { with mid. } \\
\text { diameter 7-25 cm } \\
\text { (\%) }\end{array}$ & 24 & 29 & 28 & 38 & 23 & 32 & 29 & 16 & 63 & 65 & 74 & 71 & 65 & 82 & 87 & 76 \\
\hline
\end{tabular}

in water volume [16]. In our case, sampling pieces of wood were neatly stacked into an empty vessel (box) of 1,000 liters, with inner dimensions of $100 \mathrm{~cm} x$ $100 \mathrm{~cm} \times 100 \mathrm{~cm}$ (Figure 1). Then water was poured into the vessel to the upper level of $100 \mathrm{~cm}(1,000$ I $\left.=1 \mathrm{~m}^{3}\right)$. After that we took out all the wood from the vessel and measured water level (Figure 2). In fact we determined amount of water that remains in the vessel. This amount of water actually represents air gaps between pieces of wood within one stacked cubic meter. True wood volume was determined as a difference between $1.000 \mathrm{I}\left(1 \mathrm{~m}^{3}\right)$ and the remaining volume of water. Conversion ratios were calculated as a quotient of $1 \mathrm{~m}^{3}$ solid and of $1 \mathrm{~m}^{3}$ stacked.

On the basis of described procedure, we have collected data from 16 samples with 814 pieces of wood in all. General review of collected data is given in Table 4.

\section{RESULTS AND DISCUSSION}

Overall results of the experiment are shown in Table 5. As we can see all shipments were assumed as distilling wood of 2 nd class to with corresponding conversion factor 0.65 (JUS D.B0.022).

Conversion factor based on xylometry varies considerably between $0.45-0.58$, and always is lower than stated in delivery note. This result leads to the conclusion that appliance of officially prescribed conversion factor leads to over estimation of delivered distillation wood. With that regard, there is a need for improvement of existing conversion factor on the basis of reliable data. Also results of dendrometric measurements and calculating of volume show that conversions factors are significantly lower than those one obtain with the xylometry $0.36-0.52$. Main rea-

\section{TABLE 5}

Results of experiment

\begin{tabular}{|c|c|c|c|c|c|c|c|c|c|c|c|c|c|c|c|c|}
\hline Sample Nr. & 1 & 2 & 3 & 4 & 5 & 6 & 7 & 8 & 9 & 10 & 11 & 12 & 13 & 14 & 15 & 16 \\
\hline $\begin{array}{c}\text { Conv. factor } \\
\text { stated in } \\
\text { the delivery } \\
\text { note }\end{array}$ & 0.65 & 0.65 & 0.65 & 0.65 & 0.65 & 0.65 & 0.65 & 0.65 & 0.65 & 0.65 & 0.65 & 0.65 & 0.65 & 0.65 & 0.65 & 0.65 \\
\hline $\begin{array}{c}\text { Conv. factor } \\
\text { calculated } \\
\text { byxylometry }\end{array}$ & 0.46 & 0.48 & 0.49 & 0.49 & 0.45 & 0.47 & 0.47 & 0.45 & 0.56 & 0.54 & 0.56 & 0.56 & 0.54 & 0.54 & 0.58 & 0.55 \\
\hline $\begin{array}{c}\text { Conv. factor } \\
\text { calculated } \\
\text { by Huber's } \\
\text { formula }\end{array}$ & 0.37 & 0.39 & 0.40 & 0.40 & 0.33 & 0.38 & 0.38 & 0.33 & 0.49 & 0.48 & 0.49 & 0.50 & 0.48 & 0.50 & 0.51 & 0.48 \\
\hline $\begin{array}{c}\text { Conv. factor } \\
\text { calculated } \\
\text { by Smalian's } \\
\text { formula }\end{array}$ & 0.37 & 0.39 & 0.40 & 0.40 & 0.33 & 0.38 & 0.38 & 0.32 & 0.49 & 0.47 & 0.50 & 0.50 & 0.48 & 0.50 & 0.52 & 0.48 \\
\hline $\begin{array}{c}\text { Conv. factor } \\
\text { calculated } \\
\text { by Rieckes's } \\
\text { formula }\end{array}$ & 0.36 & 0.38 & 0.41 & 0.40 & 0.33 & 0.39 & 0.38 & 0.33 & 0.49 & 0.48 & 0.50 & 0.50 & 0.48 & 0.51 & 0.52 & 0.49 \\
\hline
\end{tabular}


son for that may laying in the fact that measurements was done according to JUS which prescribes measurement with rounding down for diameter (round centimeters) and length (round decimeters). Thus, maximum error due to rounding is $9 \mathrm{~mm}$ in measuring diameter and $9 \mathrm{~cm}$ in measuring length. Relative impact of these errors on error of volume is as higher as the wood assortment is less voluminous, and vice versa. This simple rule is particularly noticeable with very small assortments such as small round billets.

There are no significant differences between different methods (formulas) of calculating volume. So we can conclude that measurement according JUS is not appropriate for assortments from the category of staked wood. Another important fact which has to be considered is moisture of wood. Volume of wood depends on moisture content. For example row wood (after cut) of beech has $14 \%$ higher volume than dry, wood of oak $11 \%$ etc. That means that conversion coefficients must be determined for different moisture content.

One solution for described gap may be shift to weight scaling. In that case mistakes caused by measurement could be avoided but it must be considered moisture of wood also. Wood for distilling should be as dry as much as possible before use, around $20 \%$ moisture content.

There are a significant number of pieces with diameter below $7 \mathrm{~cm}(13-84 \%)$ that according to JUS standard are not allowed in the 2 nd class distilling wood with conversion coefficient 0.65 .

We determined dependence between conversion coefficients and number of pieces, as well as between conversion coefficients and average diameter of pieces. We used correlation and regression analysis.

Examination of relationship between number of pieces in stacked meter and conversion coefficients obtained by xylometry we can say that with increasing of number of pieces conversion coefficients are decreasing. There is very strong dependence represented with coefficient of correlation of $R=0.98$, and coefficient of determination of $R^{2}=0.96$. Dependence is shown graphically (Figure 3 ) and represent with linear function (1).

$$
y=0,6601-0,0015 x
$$

Examination of relationship between average diameter of pieces in stacked meter and conversion coefficients obtained by xylometry we can say that with increasing of average diameter of pieces conversion coefficients are increasing also. There is very strong dependence represented with coefficient of correlation of $R=0.96$, and coefficient of determination of $R^{2}=0.93$. Dependence is shown graphically (Figure 4) and represent with linear function (2).

$$
y=0,3044+0,0288 x(2)
$$

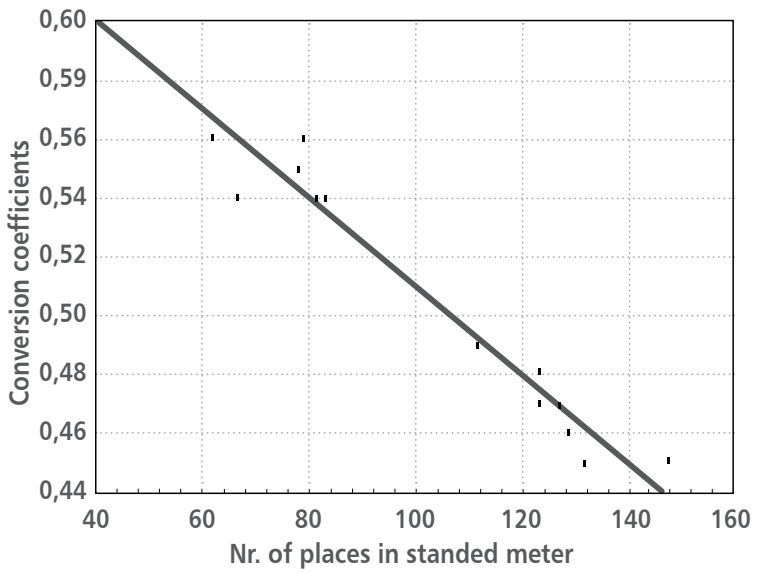

FIGURE 3

Dependence between number of pieces and conversion coefficients

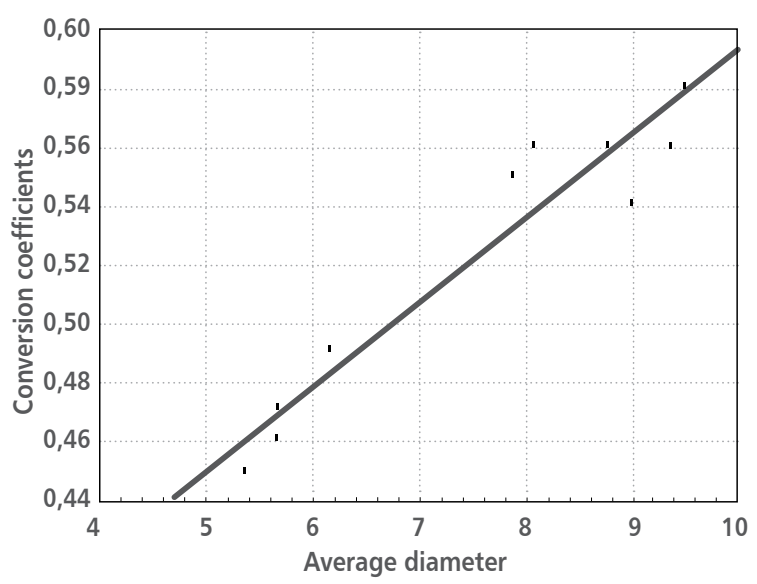

FIGURE 4

Dependence between average diameter of pieces and conversion coefficients

\section{CONCLUSIONS}

Conversion coefficients are defined in JUS standard and depend on dimensions and shapes of pieces of wood. Results of research show that conversion coefficients by JUS are not appropriate for the wood which appears as a raw material for distilling. Xylometry method show that coefficients should be significantly lower than those one prescribe in JUS standard and used in delivery notes and should be revised. We can conclude that dendrometric measurement is not adequate method for measure of stacked wood. Volume of wood depends on moisture content. For example row wood (after cut) of beech has $14 \%$ higher volume than dry, wood of oak $11 \%$ etc. Conversion coefficients must be determined for different moisture content. Solution could be shipment of distilling wood by weight scaling. In that case wood for distilling should be as dry as much as possible, around 20 $\%$ moisture content. 


\section{REFERENCES}

1. BEGOVIĆ B 1986 Eksploatacija šuma i razvoj industrijske prerade drveta na području Usorsko-teslićnog regiona za vrijeme austrougarske uprave u Bosni i Hercegovini. Savez inženjera i tehničara šumarstva i industrije za preradu drveta Bosne i Hercegovine, p 1-78

2. HEMIJSKA INDUSTRIJA DESTILACIJA A.D. TESLIĆ 20080 Destilaciji. Available at: http://www.destilacija.rs.ba/ (Accessed: 21 November 2010)

3. JUGOSLOVENSKI INSTITUT ZA STANDARDIZACIJU 1984 JUS D.BO.022

4. JUGOSLOVENSKI INSTITUT ZA STANDARDIZACIJU 1984 JUS

5. THIVOLLE-CAZAT A 2008 Conversion factors. A necessity fo an accurate estimation of wood consuption by industries. Pôle Economie, Energie et prospective Institut Technologique FCBA, p 1-12

6. UNECE, FAO 2010 Forest product conversion factors for the UNECE region. Geneva Timber and Forest Discussion Paper 49, p 1-38

7. ALAKANGAS E 2005 Properties of wood fuels used in Finland. Technical Research Centre in Finland, VTT Processes, Project report PRO2/P2030/05, p 1-31

8. THE EEUROPEAN COMMISSION 2010 Combined Nomenclatureen. Chapter 44, Wood and articles of wood; wood charcoal. Official Journal of the European Union 29.10.2010, p 305-315

9. HORVAT I, KRPAN J 1967 Drvno industrijski priručnik. I dio

10. GORNIK BUČAR D, MERZEL F 1998 Žagarski praktikum. Ljubljana, Biotehniška fakulteta, p 151

11. PIRINENE H 1996: Bulk and stack density of chopped wood. TTS-Institute. Hand-outs 6/1966 (48): 1-32

12. KOFMAN D P 2006 Characteristics of firewood. Harvesting/ Transportation No. 5. Coford. Danish Forestry Extension, $p$ 1-4

13. JENNINGS L G 1965 A glossary of log and timber measures. Wood (magazine) August-December.

14. FLANN I B 1962 Some conversion factors and related information for use in the primary forest industry of Eastern Canada. Tech. Note 26. Departement of Forestry. Forest Products Research Branch. Otawa, Canada.

15. EN 1309-2 2006 Round and sawn timber - Method of measurement of dimensions - Part 2: Round timber - Requirements for measurement and volume calculation rules, $p$ 1-16

16. ÖZÇELIK R, WIANT V H, BROOKS R J 2008 Accuracy using xylometry of log volume estimates for two tree species in Turkey. Scand J Forest Res 23 (3): 272-277 